\title{
PELAYARAN RAKYAT DALAM PERSPEKTIF SISTEM LOGISTIK NASIONAL
}

\author{
Yusuf Romadhon dan Resista Vikaliana \\ Institut Ilmu Sosial dan Manajemen STIAMI \\ email korespondensi: resistav31@gmail.com
}

\begin{abstract}
Abstrak. Negara Indonesia adalah negara yang menurut sejarah budaya dan pada zaman kerajaan merupakan negara bahari. Negara Indonesia dengan kepulauan terluas meliputi laut terluas, pulau terbanyak, dan pantai terpanjang kedua di dunia. Atas dasar tersebut, Indonesia saat ini memiliki pelabuhan moderen dan juga pelabuhan untuk pelayaran rakyat. Pelayaran rakyat pada umumnya identik dengan kapal kayu tradisional yang dioperasikan oleh pelaut alami dengan manajemen sederhana (UU NO 17/ 2008 tentang pelayaran pasal 15 ayat 1 dan 2). Tuntutan bisnis global menyebabkan pelayaran rakyat saat ini terpinggirkan.

Beberapa permasalahan dalam pelayaran rakyat di antaranya pengadaaan armada pelayaran terhambat oleh sulitnya penyediaan kayu gelondongan, sehingga perlu dicarikan alternatif lain. Permasalahan lainnya adalah jaminan keselamatan dan pelayanan yang baik dari pelayaran rakyat

Pemerintah berencana membangun Pelabuhan Rakyat. Pelabuhan ini nantinya akan dibangun dengan sistem keamanan yang baik. Penataulangan pelayaran rakyat dengan zona tersendiri. Pelayaran rakyat masih dibutuhkan, sebab daerah terpencil yang tidak dilintasi kapal besar otomatis masih bergantung pada kapal ukuran kecil semacam KLM maupun PLM. Selain itu, ada dermaga yang tidak bisa disandari kapal besi atau pelabuhan dangkal. Pelayaran rakyat dapat mengatasi hal itu, sehingga membantu transpotasi nasional.

Indonesia sebagai negara kepulauan terbesar masih tetap membutuhkan pelayaran rakyat sebagai salah satu moda transportasi antar pulau. Pemerintah berkomitmen untuk memordenisasi dan meningkatkan keselamatan dan keamanan pelayaran rakyat dengan tetap mempertimbangkan kearifan lokal. Permasalahan lainnya adalah jaminan keselamatan dan pelayanan yang baik dari pelayaran rakyat.
\end{abstract}

Kata kunci: pelayaran rakyat, pelabuhan rakyat, sistem logistik nasional

\begin{abstract}
The State of Indonesia is a country which is according to cultural history and in the days of the kingdom is a maritime country. The country of Indonesia with the largest islands covers the largest sea, the largest island, and the second longest beach in the world. On this basis, Indonesia currently has a modern port as well as a port for people's voyages. People's voyages are generally identical to traditional wooden boats operated by natural sailors with simple management (Law No. 17/2008 on the voyage of articles 15, paragraphs 1 and 2). The demands of global business are causing people's shipping today to be marginalized.

Some problems in the voyage of the people include the procurement of the shipping fleet is hampered by the difficult supply of logs, so it needs to look for other alternatives. Another problem is the guarantee of safety and good service from the voyage of the people

The government plans to build the People's Port. This port will be built with a good security system. The sailing of people with the zone of its own. People's voyages are still needed, because remote areas that are not crossed by large auto ships are still dependent on small ships such as KLM or PLM. In addition, there is a dock that can not be enclosed by iron vessels or shallow harbors. The voyage of the people can overcome it, thus helping national transpotation.
\end{abstract}


Indonesia as the largest archipelago country still requires the voyage of the people as one mode of inter island transportation. The Government is committed to memordenisasi and improve the safety and security of people's shipping by still considering local wisdom. Another problem is the guarantee of safety and good service from the voyage of the people.

Keywords: people's voyage, people's port, national logistics system

\section{PENDAHULUAN}

Negara Indonesia adalah negara yang menurut sejarah budaya dan pada zaman kerajaan merupakan negara bahari. Negara Indonesia dengan kepulauan terluas meliputi laut terluas, pulau terbanyak, dan pantai terpanjang kedua di dunia. Indonesia memiliki sumber daya alam ke dua dunia, baik di darat maupun di laut. Lokasi Indonesia sangat strategis dalam sistem industri dan perdagangan antar bangsa.

Atas dasar tersebut, Indonesia saat ini memiliki pelabuhan moderen dan juga pelabuhan untuk pelayaran rakyat. Pelayaran rakyat pada umumnya identik dengan kapal kayu tradisional yang dioperasikan oleh pelaut alami dengan manajemen sederhana (UU NO 17/ 2008 tentang pelayaran pasal 15 ayat 1 dan 2). Tuntutan bisnis global menyebabkan pelayaran rakyat saat ini terpinggirkan.

Beberapa permasalahan dalam pelayaran rakyat di antaranya pengadaaan armada pelayaran terhambat oleh sulitnya penyediaan kayu gelondongan, sehingga perlu dicarikan alternatif lain. Alternatif lain tersebut misalnya dengan pengadopsian cara perancangan dan pembangunan kapal kayu moderen untuk diterapkan kepada kapal armada pelayaran rakyat. Permasalahan lainnya adalah jaminan keselamatan dan pelayanan yang baik dari pelayaran rakyat, diperlukan pembinaan dan pengawasan yang lebih konsisten dan menyeluruh oleh pemerintah yang bekerja sama dengan asosiasi atau koperasi yang ada. Pemerintah juga diamanatkan untuk mengembangkan pelayaran rakyat dengan langkah-langkah dalam PM 93/ 2013 tentang penyelenggaraan angkutan laut. Pengembangan itu termasuk penyediaan pelabuhan yang memadai, kemudahan pengembangan serta penyediaan BBM bersubsidi.

\section{PERUMUSAN MASALAH}

Bagaimana fungsi dan peran pelayaran rakyat dalam sistem logistik nasional?

\section{TUJUAN PENULISAN}

Mengkaji fungsi dan peran pelayaran rakyat dalam sistem logistik nasional

\section{TINJAUAN PUSTAKA}

Transportasi adalah Salim (2000) kegiatan pemindahan barang (muatan) dan penumpang dari suatu tempat ke tempat lain. Dalam transportasi ada dua unsur yang terpenting yaitu pemindahan/pergerakan (movement) dan secara fisik mengubah tempat dari barang (comoditi) dan penumpang ke tempat lain.

Menurut Miro (2005) Transportasi dapat diartikan usaha memindahkan, mengerakkan, mengangkut, atau mengalihkan suatu objek dari suatu tempat ke tempat lain, di mana di tempat lain ini objek tersebut lebih bermanfaat atau dapat berguna untuk tujuan-tujuan tertentu. Sedangkan menurut Nasution (2008) adalah sebagai pemindahan barang dan manusia dari tempat asal ke tempat tujuan.

\section{Kondisi transportasi laut nasional}

saat ini berdasarkan peringkat indeks konektivitas Indonesia di sektor transportasi laut, pada tahun 2014 
meningkat menjadi 77 dibandingkan tahun 2012 (peringkat 2012). Peringkat tersebut masih jauh lebih rendah dibandingkan Thailand dan Malaysia. Skor LPI (Logistic Performance Index) meningkat 0,14 dibandingkan tahun 2012, peringkat global naik dari 59 menjadi 53. Tantangannya adalah infrastruktur dalam perbaikan sistem rantai pasok.

\section{Fungsi Pelabuhan dan Perkembangan- nya}

\section{Pelabuhan adalah}

Masalah kepelabuhan adalah hal-hal yang menyangkut hubungan antara kapal, muatan dan jasa pelabuhan. Kapal memerlukan tempat bersandar di dermaga dan memerlukan berbagai pelayanan selama di pelabuhan. Muatan memerlukan jasa terminal di pelabuhan dalam proses peralihan dari kapal ke angkutan darat. Pelabuhan menyediakan jasa-jasa bagi kapal dan muatan agar tidak tejadi hambatan dalam pelayaran kapal dan arus barang serta arus penumpang. Dalam memberikan jasa-jasa pelabuhan, pelabuhan memiliki beberapa prasarana, yaitu dermaga, terminal, gudang, lapangan penimbunan, navigasi dan telekomunikasi, peralatan bongkar muat dan perkantoran. (Nasution, 2008: 198)

Pelabuhan merupakan suatu unit transportasi dan unit ekonomi yang berperan utnuk merangsang pertumbuhan dan perkembangan perdagangan/ perekonomian, yang teridiri atas kegiatan penyimpanan, distribusi, pemrosesan, pemasaran dan lainnya. Pengertian pelabuhan yang sekaligus juga mencerninkan fungsi pelabuhan sebagai inter face, link (mata rantai) transportasi dan pelabuhan sebagai gateway serta pelabuhan sebagai industry entity (pintu gerbang dan daerah industri). Peranan pelabuhan meliputi:
1. Untuk melayani kebutuhan perdagangan internasional dari daerah

2. Membantu berputarnya roda perdagangan dan pengembangan industri regional

3. Menampung pangsa pasar yang makin meningkat dari lalu lintas internasional, baik transhipment maupun barang.

4. Menyediakan fasilitas transit untuk daerah belakang atau daerah/ negara tetangga.

(Nasution, 2008).

Suatu pelabuhan yang dikelola dengan efisien yang dilengkapi dengan fasilitas yang memadai akan membawa keuntungan dan dampak positif bagi perdagangan dan perindustrian di lokasi tempat pelabuhan tersebut berada. Sebaliknya, perdagangan yang lancar dan perindustrian yang tumbuh dan berkembang membutuhkan jasa pelabuhan yang makin meningkat yang akan mengakibatkan perkembangan pelabuhan.

Perkembangan pelabuhan lebih meningkat lagi setelah adanya pelabuhan bebas yang merupakan indikasi bahwa pelabuhan merupakan sluatu unit dalam sistem ekonomi secara keseluruhan dan tidak dapat dipisahkan dengan kondisi ekonomi daerah yang dilayani oleh pelabuhan tersebut. Perkembangan perdagangan dunia yang cepat mengakibatkan banyak prasarana harus disesuaikan untuk memberikan pelayanan pelabuhan yang lebih baik, sehingga memerlukan invesatasi yang besar.

Di Indonesia terdapat 336 pelabuhan besar dan kecil yang terdiri atas 51 pelabuhan laut, 38 pelabuhan pantai yang terbuka untuk ekspor imporl, 164 pelabuhan pantai umum, 67 pelatihan pantai khusus, dan 16 pelabuhan khusus. Dari pelabuhanpelabuhan tersebut, hanya 87 pelabuhan yang dikelola oleh PT Pelabuhan 
Yusuf Romadhon dan Resista Vikaliana, Pelayaran Rakyat Dalam Perspektif Sistem....

Indonesia (PT Pelindo) I-IV. 87 pelabuhan yang dikelola oleh PT Pelindo tersebut dibedakan atas kelas pelabuhan, yaitu Kelas I sebanyak 4 pelabuhan, kelas II sebanyak 15 pelabuhan, kelas III sebanyak 21 pelabuhan, kelas IV sebanyak 31 pelabuhan dan kelas V sebanyak 16 pelabuhan. (Nasution, 2008). Berikut adalah rincian jumlah pelabuhan yang dikelola oleh PT Pelindo

Tabel 1. Jumlah Pelabuhan PT Pelindo

\begin{tabular}{|l|l|l|}
\hline \multicolumn{1}{|c|}{ PT Pelindo } & \multicolumn{1}{c|}{ Jumlah Pelabuhan } & \multicolumn{1}{c|}{ Panjang Darmaga } \\
\hline Pelindo I & 10 & $9.850 \mathrm{~m}$ \\
\hline Pelindo II & 19 & $18.712 \mathrm{~m}$ \\
\hline Pelindo III & 28 & $20.673 \mathrm{~m}$ \\
\hline Pelindo IV & 21 & $8.124 \mathrm{~m}$ \\
\hline
\end{tabular}

Pelabuhan yang memiliki fasilitas moderen dan lengkap adalah Tanjung Priok, Belawan, Tanjung Perak, dan Ujung

\section{PEMBAHASAN}

Pemerintah berencana membangun Pelabuhan Rakyat. Pelabuhan ini nantinya akan dibangun dengan sistem keamanan yang baik. Menurut Menteri Perhubungan (Budi Karya), pemerintah masih memikirkan lebih jauh mengenai rencana ini. Pembahasan pun masih akan dilakukan dengan pemerintah daerah. Ada entitas yang tanggung jawab dan yang bertanggung jawab memesan kepada industri perkapalan, sehingga industri perkapalan tetap jalan, dana yang keluarkan Rp1 triliun dalam 5 tahun, dan pelayaran rakyat bisa beroperasi dengan kapal-kapal yang lebih bersih .

Penataulangan pelayaran rakyat dengan zona tersendiri. Pelayaran rakyat masih dibutuhkan, sebab daerah terpencil yang tidak dilintasi kapal besar otomatis masih bergantung pada kapal ukuran kecil semacam KLM maupun PLM. Selain itu, ada dermaga yang tidak bisa disandari kapal besi atau pelabuhan dangkal. Pelayaran rakyat dapat mengatasi hal itu, sehingga membantu transpotasi nasional. Pemerintah pun berencana akan memberikan subsidi kepada kapal-kapal dalam pelabuhan rakyat. Namun, nantinya
Pandang. Pelabuhan-pelabuhan ini mengarah pada pelabuhan kontainer.

rencana ini akan kembali dibahas lebih lanjut oleh internal pemerintah.

Sebagai contoh pelayaran rakyat adalah Pelabuhan Kalimas. Pelabuhan Kalimas ini menarik untuk dikunjungi, karena memiliki pemandangan yang kontras, beda dan unik. Pelabuhan kalimas merupakan pelabuhan tradisional, dengan kapal-kapal tradisional. Bongkar muat pun terkadang masih tradisional, mengunakan buruh angkut.Ada 2 jenis kapal yang bersandar di pelabuhan kalimas. Kapal Layar Motor (KLM) yang berbahan dasar dari kayu dan Kapal Motor (KM) yang terbuat dari besi. Rata-rata kapal-kapal tersebut berukuran 10 meter. Kapal-kapal tersebut mengangkut bahan-bahan kebutuhan pokok ke daerah di luar pulau jawa. Biasanya daerah tujuan yang tidak bisa dijangkau oleh kapal-kapal besar.

Contoh lainnya adalah Pelabuhan Rakyat Gresik. Pelabuhan ini masih diperlukan dan dikelola di bawah kewenangan Pelindo III. Pelabuhan ini berperan sebagai pusat pelabuhan curah kering, log kayu, dan batubara. Fungsi tersebut adalah fungsi yang tidak dilayani oelh pelabuhan lain di dekatnya. Zona petikemas bertonase besar berada di Pelabuhan Tanjung Perak Surabaya dan Teluk 
Lamong. Pelabuhan Indonesia III (persero) Cabang Gresik membangunkan fasilitas dermaga yang modern. Jadi tidak serta merta dengan adanya modernisasi pelabuhan dan penambahan 4 unit fix crane. Pelayaran rakyat tidak dikesampingkan, hanya ditata supaya dengan adanya fasilitas modern dan resprentatif. Arus bongkar muat barang yang menggunakan jasa pelabuhan rakyat bisa meningkat.

Rencana pembuatan suatu sistem pelayanan pelayaran rakyat yang baik oleh pemerintah adalah dengan penerapan tingkat keamanan (safety) yang lebih baik. Sistem tersebut akan dilaksanakan dengan penerapan ramp check reguler. Penerapan ini menjadi kewajiban bagi KSOP (Kantor Kesyahbandaran dan Otoritas Pelabuhan) dengan pemilik kapal untuk mengevaluasi terus-menerus. Setelah itu, perlu melakukan persiapan saat berangkat dan mengikuti semua prosedur yang sudah ditetapkan.

Pelayaran rakyat adalah hak hidup masyarakat banyak, sehingga kementerian perhubungan berencana pula melakukan suatu reformasi yang berdasarkan kepentingan masyarakat. Sebagai pilot project program reformasi pelayaran rakyat adalah Provinsi DKI Jakarta.

\section{SIMPULAN}

Indonesia sebagai negara kepulauan terbesar masih tetap membutuhkan pelayaran rakyat sebagai salah satu moda transportasi antar pulau. Pemerintah berkomitmen untuk memordenisasi dan meningkatkan keselamatan dan keamanan pelayaran rakyat dengan tetap mempertimbangkan kearifan lokal.

\section{DAFTAR PUSTAKA}

Abbas, Salim. 2000. Manajemen

Transportasi. Cetakan Pertama. Edisi

Kedua. Ghalia Indonesia. Jakarta.
Astuti, Sri Retna, Dwi Ratna Nurhajarin dan Nurdiyanto. 2016. Pembangunan Pelabuhan Surabaya Dan Kehidupan Sosial Ekonomi di Sekitarnya Pada Abad XX BPNB D. I. Yogyakarta

Miro, F. 2002. Perencanaan Transportasi, Erlangga, Jakarta.

Nasution,M. N. 2008. Manajemen

Transportasi. Ghalia Indonesia, Jakarta

Sumber Internet

https://m.tempo.co/read/news/2017/01/10/ 090834624/pelayaran-rakyat-akandireformasi-ini-target-menteri-budi http://beritajatim.com/ekonomi/251145/jan gan_lupakan_pelabuhan_rakyat.html http://economy.okezone.com/read/2017/01 /26/320/1601791/pelabuhan-rakyatdibangun-kapal-kayu-eksotis-tetapdipertahankan .By Pehttps://pesonawisatasurabaya.wordpress. com/tag/pelabuhan-rakyat/ 